Endocrinol. Japon., Vol. 3, No. 4 (1956).

\title{
EFFECT OF GROWTH HORMONE AND CORTISONE ACETATE UPON MITOTIC ACTIVITY IN NORMAL AND REGENERATING TISSUES OF AMPHIBIA
}

\author{
SAKAE INOUE \\ Section of Biological Research, Endocrinological Laboratories, School \\ of Medicine, Gunma University, Maebashi
}

The outburst of mitotic activity in regenerating tissues of amphibia has been demonstrated by a number of workers. In the series of studies on the above mentioned phenomenon, the writer has reported that mitotic activity in regenerating tissues of the limb and dorsal skin is inhibited by hypophysectomy (Inoue, 1956). To study the results obtained by hypophysectomy, the effects of several hormones on mitotic activity in the normal and regenerating tissues of amphibia were observed.

The present report is concerned with the effects of growh hormone and cortisone acetate on the regenerating epidermis, on tissues of some viscera of adult newt and normal epidermis of anuran tadpoles.

\section{MATERIALS AND METHODS}

The experiments were carried out in June with adults of the common newt, Triturus pyrrhogaster, and the two-year-old larvae of the bull frog. In observing the epidermal mitotic activity in regenerating tissues of the adult newt, the left forelimb of each individual was amputated at the midst of the stylopodium with subsequent extirpation of the remaining humeral bone. The removed limbs were fixed separately in Bouin's solution as the samples for the control datum corresponding to each experimental individual. Adult newts in each experiment received daily subcutaneous injections of $0.1 \mathrm{ml}$ or $0.15 \mathrm{ml}$ of 0.7 per cent saline containing the desired doses of cortisone acetate (Scherring), ACTH (Scherring) and growth hormone (Armour Lot \#285128). The larvae of the bull frog were injected subcutaneously at the dorsal side of the trunk, cortisone acetate and growth hormone with the daily dose of $0.3 \mathrm{mg}$ and $25 \gamma$ respectively per individual using $0.1 \mathrm{ml}$ solution each. The specimens were fixed whole in Bouin's solution. Tissues to be investigated were dissected out from the fixed materials and subjected to routine histological procedure, sectioned serially at $8 \mu$ and stained with Delafield's hematoxylin and eosin. Rate of mitosis was calculated by counting the resting and mitotic cells according to the method previously reported (Inoue, 1956) in the stump epidermis continuing to the wound of limb in about $2 \mathrm{~mm}$ range from the periphery of the latter, corresponding control epidermis, liver, small intestine of the adult newt and ventral fin at the midst of the tail of the larval bull frog.

\footnotetext{
Received for publication October 25, 1956
} 


\section{RESULTS}

1. Effect upon epidermal mitotic activity in regenerating forelimbs of adult newts

Simultaneous with the limb amputation, the animals were injected subcutaneously with growth hormone in the dosages of $0.5 \sim 100 \gamma$ and cortisone acetate in dosages of $0.005 \sim 1 \mathrm{mg}$ per individual. Rates of the mitosis established in the epidermis of the regenerated limb after administration of four times consecutive daily injections of hormones of the mentioned doses are represented in Table 1.

In the series of experiments, the outburst of mitotic activity in regenerating epidermis took place already within four days after limb amputation as was manifested in the saline injected control. Following administration of growth hormone, the epidermis exhibited high level of mitosis-rates form 1.82 to 3.07 per cent with graded activity corresponding to the doses administered. These obtained mitosis-rates were singnificantly higher than the level of the saline injected case $\left(\mathrm{p}<0.01\right.$ in $\chi^{2}$ test $)$ as well as the corresponding datum in control

Table 1. Mitosis-rates of epidermal cells in the regenerating limb of the adult newt as a result of the ddministration of different doses of growth hormone and cortisone acetate

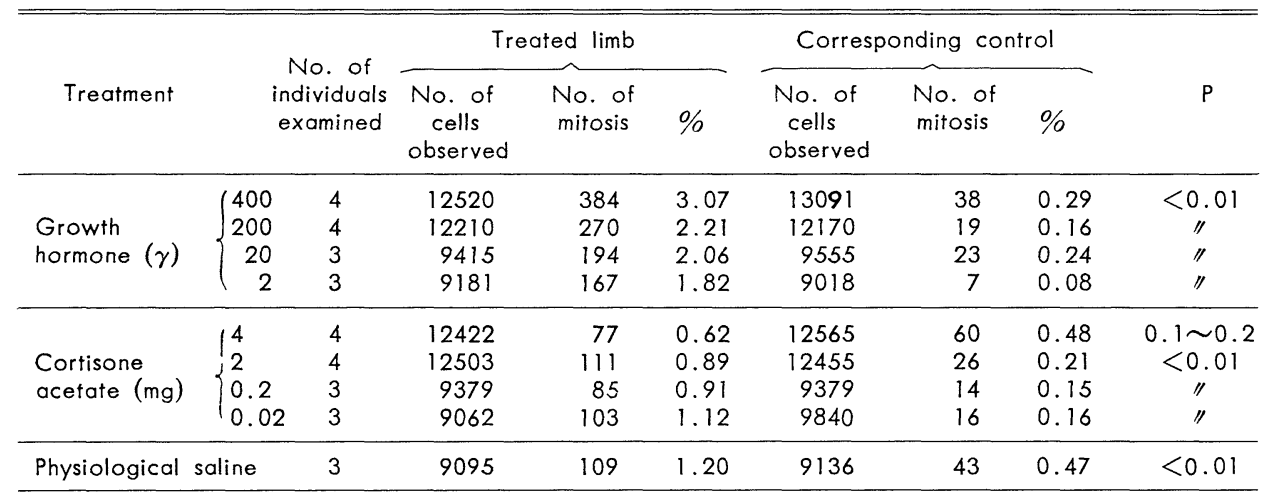

epidermis. The result shows evidently that the outburst of mitotic activity in regenerating epidermis is accelerated by the administration of growth hormone in the doses used. On the other hand, epidermal cells treated with cortisone acetate showed mitosis rates ranging from 0.62 to 1.12 per cent. Among them, the rates obtained by the low doses $(0.02 \sim 2 \mathrm{mg}$ in total dose), though they were significantly higher than the corresponding controls, were not so significant as compared with the rate of the saline injected case $\left(0.1>p>0.05\right.$ in $\chi^{2}$ test). However, the rate of 0.62 per cent established by the injection of cortisone acetate in the dose of $4 \mathrm{mg}$ in total was not so significant as compared with that of the corresponding control. This was also significantly lower than the rate of the saline injected case $\left(p<0.01\right.$ in $\chi^{2}$ test). It can be stated on the basis of observations that the outburst of mitotic activity in the regenerating epidermis is. inhibited when $4 \mathrm{mg}$ of cortisone acetate in total was administered. 
2. Effect upon mitosis-rate in epidermis, replacing cells of small intestine and cortical part of liver of adult newt

The rates of mitosis in the epidermis of a part of the abdominal skin, the replacing cells of small intestine and the cortical part of the liver of the adult newt which were established by four times consecutive daily injections of growth hormone and cortisone acetate in the doses $400 \gamma$ and $4 \mathrm{mg}$ in total respectively were manifested as shown in Table 2. Comparison of mitosis rates exhibited by the three investigated tissues indicates that only epidermal cells were responsive to the hormone administration. That is, the epidermal mitosis-rate obtained by injecting the growth hormone was markedly significant as compared with the control level $\left(\mathrm{p}<0.01\right.$ in $\chi^{2}$ test). Also considerably low mitotic activity could be detected in the epidermis following administration of cortisone acetate and the

Table 2. Effects of cortisone acetate $(4 \mathrm{mg}$ per individual) and growth hormone $(400 \gamma$ per individul) upon mitotic activity in the epidermis, replacing cells of the small Intestine and cortical part of the liver of the adult newt in three or four individuals in each

\begin{tabular}{|c|c|c|c|c|c|c|c|c|c|}
\hline \multirow[b]{2}{*}{ Tissues } & \multicolumn{3}{|c|}{ Growth hormone } & \multicolumn{3}{|c|}{ Cortisone acetate } & \multicolumn{3}{|c|}{ Physiological saline } \\
\hline & $\begin{array}{l}\text { No. of } \\
\text { cells } \\
\text { observed }\end{array}$ & $\begin{array}{l}\text { No. of } \\
\text { mitosis }\end{array}$ & $\%$ & $\begin{array}{l}\text { No. of } \\
\text { cells } \\
\text { observed }\end{array}$ & $\begin{array}{l}\text { No. of } \\
\text { mitosis }\end{array}$ & $\%$ & $\begin{array}{l}\text { No. of } \\
\text { cells } \\
\text { observed }\end{array}$ & $\begin{array}{l}\text { No. of } \\
\text { mitosis }\end{array}$ & $\%$ \\
\hline $\begin{array}{l}\text { Cortical part } \\
\text { of liver }\end{array}$ & 12313 & 191 & 1.55 & 12441 & 186 & 1.49 & 9148 & 145 & 1.58 \\
\hline $\begin{array}{l}\text { Replacing cells } \\
\text { of small intestine }\end{array}$ & 12762 & 200 & 1.51 & 12650 & 169 & 1.34 & 6669 & 79 & 1.18 \\
\hline Epidermis & 12563 & 227 & 1.81 & 12499 & 40 & 0.32 & 9384 & 42 & 0.42 \\
\hline $\begin{array}{l}\text { Corresponding } \\
\text { control in } \\
\text { epidermis }\end{array}$ & 13090 & 38 & 0.29 & 12565 & 60 & 0.48 & 9136 & 43 & 0.47 \\
\hline
\end{tabular}

resulted rate of 0.32 per cent was significantly lower than that of the corresponding control calculated with pieces of limb skin excised previous to the hormone adminisration $\left(0.05>\mathrm{p}>0.02\right.$ in $\chi^{2}$ test $)$.

In spite of thus mentioned responsiveness of epidermal cells, no significant influence in mitosis-rate could be detected among the replacing cells of the small intestine $\left(0.2>p>0.1\right.$ in $\chi^{2}$ test $)$ and the cortical part of the liver $(0.98>p>0.95$ in $\chi^{2}$ test) in the same specimens in which were observed the epidermal mitosis-rates.

3. Effect upon mitosis-rate in the epidermis of larval bull frog

On the second, fourth, sixth, and eighth days after daily subcutaneous injections of growth hormone, cortisone acetate in doses mentioned and 0.7 per cent saline, four or six individuals were fixed and observed mitosis-rates with the histological preparations. Per mille mitosis-rates in the ventral fin at the midst of the tail counted by observing the total of about 10,000 to 15,000 epidermal cells in each group are presented graphically in Fig. 1. Following the administration of growth hormone, a remarkable increase in mitotic activity was detected only 
at the period four days after treatment and the obtained rate of 1.4 per cent was highly significant as compared with that obtained at the other periods. In six-day-specimens, the rate of mitosis was reduced to 0.48 per cent which was not significant as compared with the saline injected control.

In the course of the experiment under the conditions mentioned, occurrence of metamorphosis was the case by administration of growth hormone which is presumably due to the thyrotrophic hormone contaminated slightly in this preparation. The growth of the hindlimb became noticeable at about six days in which period redution of mitotic activity happened in the epidermis.

Cortisone acetate did not influence seriously on the mitotic activity under the dose administered as

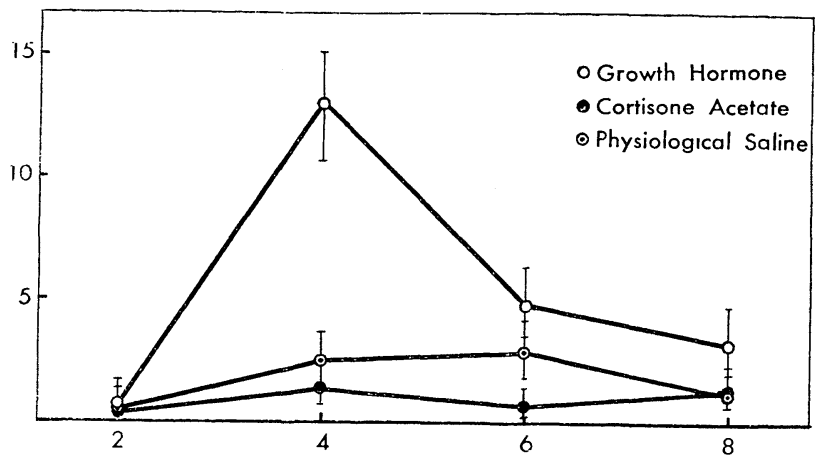

Fig. 1. Infiuence of cortisone acetate, growth hormone and physiological saline on mitotic activity in the epidermis of the larval bull frog. Confidence limit: 98 per cent the case established by growth hormone. But, in some cases, slight anti-mitotic effect could be detected in the course of this experiment.

\section{CONSIDERATIONS}

The nature of adrenocorticotrophic and adrenocortical hormones upon woundhealing is inhibitory as frequently reported in the experiments carried out with mammals (Reid, 1954). In the study of regeneration in amphibia, it was postulated that the xenoplastical transplantation of frog adrenals (Schotté and Lindberg, 1954), the administration of cortisone and ACTH (Bragdon and Dent, 1954) had no effects upon the regeneration process of hypophyse intact adult newt, Triturus viridescens, on the contrary, ACTH had an inhibitory effect upon the early phases of regeneration (Schotté and Chamberlain, 1955). In relation to the hormonal effects upon mitotic activity in regenerating tissues, it was reported that no effects could be demonstrated in the regenerating tissues of the limb by the administration of cortisone acetate using several dosage levels whose maximum was $0.5 \mathrm{mg}$ per day (Bragdon and Dent, 1954). But, Manner (1955) reported mitosis-inhibitory effect of cortisone on regenerating epidermis and mesodermal tissues in the daily dose of $0.0005 \mathrm{mg}$ per individual with subsequent stimulation during the first eight post-operative day, using the adult newts of the above mentioned species. Further, inhibitory effect of cortisone and ACTH upon the mitotic division of some sea-urchin eggs was reported by Menkin and Pepper (1955). In the author's experiments, though the lower doses of cortisone acetate exhibited no distinct effects upon the regenerating epidermis, the inhibitory effect upon mitotic activity 
in the epidermis of four days' regenerated limb as well as in the normal epidermis was demonstrated among the cases which received cortisone acetate in the dose of $4 \mathrm{mg}$ per individual in total. The results together with the data mentioned above stress the inhibitory nature of adrenocortical substances upon proliferation of amphibian cells as in the case of the mammal.

Previously reported data concerning the effects of growth hormone on regeneration show growth and differention-promotive in the adult newt (Richardson, 1940) or inconsistent according to the period of administration in larval anura (Herrell, 1934; Puckett, 1938). The results reported here show that growth hormone acts as mitosis-stimulator upon both normal and regenerated epidermis of the adult newt. But in the case of the tadpole the temporal mitosis stimulation attended with subsequent reduction could be demonstrated in the epidermis of the dorsal fin four days after administration of the growth hormone. As mentioned, administration of growth hormone causes the metamorphosis of tadpole. Judging from the corresponding occurrences of noticeable metamorphic growth of the hindlimb and reduction of mitotic activity in the epidermis, the latter phenomena detected at the six post-operative day may acount for the decline of responsiveness in epidermal cells caused by the contaminated thyrotrophic hormone. The results are suggestive so far as larval amphibia are concerned, the changes of responsiveness of cells caused by the contaminants may be important as a factor influencing the proliferative phenomena in question.

In the present experiment the cortical parts of the liver and replacing cells of the small intestine showed no significant consequence by the administrations of cortisone acetate and growth hormone under the conditions of the experiment here reported. These results indicate the differences of sensitivity according to tissues upon the hormonal action under discussion and are consistent with the report of Teir and Ravanti (1953) who mention that cortisone is not so anti-mitotic in the intestine and the liver as in the epidermis of the rat.

\section{SUMMARY}

Effects of growth hormone and cortisone acetate upon mitotic activity in amphibian tissues were studied.

Following daily administrations of growth hormone in the doses of $2 \sim 400 \gamma$ in total, mitotic stimulation was demonstrated in the regenerating and normal epidermis in the four post-operative day. Also temporal stimulation of mitotic activity was demonstrated in the larval bull frogs six days after injection of the daily dose of $25 \gamma$ attended with subsequent reduction in activity.

Inhibition of mitotic activity was the case in the epidermis of the normal and the regenerating limb when four consecutive daily injections of cortisone acetate in the dose of $4 \mathrm{mg}$ in total were received subcutaneously. But no significant effects could be demonstrated on the mitotic activity of the regenerating epidermis of the adult newt following administration of lower dosage levels of $0.05 \sim 2 \mathrm{mg}$ in total.

After the inspection of mitosis-rate in the epidermis, replacing cells of the small intestine and cortical parts of the liver of the adult newt received growth hor- 
mone and cortisone acetate in the dosage level of $400 \mathrm{\gamma}$ and $4 \mathrm{mg}$ in total respectively, only epidermal cells were responsive to the administration of the hormones.

\section{ACKNOWLEDGMENT}

The author is indebted to Professor K. Shibata of Gunma University for supplying the growth hormone which was obtained through the courtesy of Dr. S. L. Steelman of Armour Laboratories.

\section{REFERENCES}

Bragdon, D. E. and J. N. Dent (1954). Proc. Soc. Exp. Biol. Eீ Med. 87, 460.

Herrel, W. E. (1934). Anat. Rec. 59, 47.

Inoue, S. (1956) Endocrinol. Japon. 3, 158

Manner, H. W. (1955). Growth 14, 169.

Menkin, V. and M. Pepper (1954). Biol Bull. 107, 316.

Puckett, W. O. (1938). Anat. Rec. 71, 337.

Reid, E. (1954). Cancer Res. 14, 249.

Richardson, D. (1940). J. Exp. Zool. 83, 407.

Schotté, O. E. and J. L. Chamberlain (1955). Rev. suisse Zool. 62, 253.

Schotté, O. E. and A. B. Lindberg (1954). Proc. Soc. Exp. Biol. E Med. 87, 26.

Teir, H. and K. Ravanti (1953). Exp. Cell Res. 5, 500. 